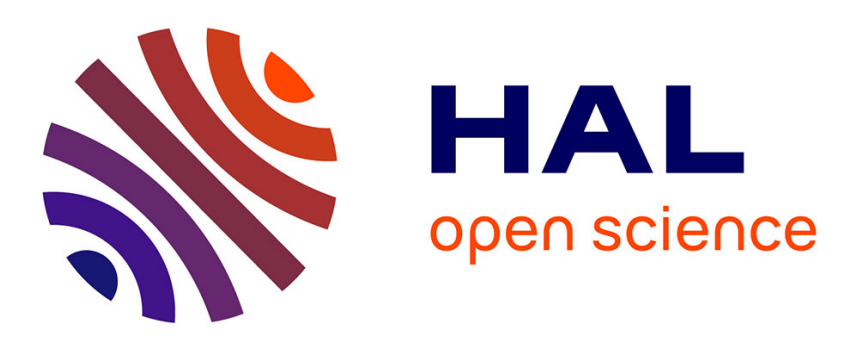

\title{
Home away from home: A longitudinal study of the holiday appropriation process
}

Isabelle Frochot, Dominique Kreziak, Elliot Statia

\section{To cite this version:}

Isabelle Frochot, Dominique Kreziak, Elliot Statia. Home away from home: A longitudinal study of the holiday appropriation process. Tourism Management, 2019, 71, pp.327-336. halshs-01957554

\section{HAL Id: halshs-01957554 \\ https://shs.hal.science/halshs-01957554}

Submitted on 17 Dec 2018

HAL is a multi-disciplinary open access archive for the deposit and dissemination of scientific research documents, whether they are published or not. The documents may come from teaching and research institutions in France or abroad, or from public or private research centers.
L'archive ouverte pluridisciplinaire $\mathbf{H A L}$, est destinée au dépôt et à la diffusion de documents scientifiques de niveau recherche, publiés ou non, émanant des établissements d'enseignement et de recherche français ou étrangers, des laboratoires publics ou privés. 
Home away from home: a longitudinal study of the holiday appropriation process

Frochot Isabelle Dr. *

Université Savoie Mont Blanc

BP 1104

73011 Chambéry Cedex

FRANCE

Isabelle.frochot@univ-smb.fr

Kreziak Dominique Dr.

Université Savoie Mont Blanc

BP 1104

73011 Chambéry Cedex

FRANCE

Dominique.kreziak@univ-smb.fr

Elliot Statia Dr.

School of Hospitality, Food and Tourism Management

University of Guelph

50 Stone Road East

Guelph, Ontario N1G2W

CANADA

Statia@uoguelph.ca

(*Corresponding author)

Home away from home: a longitutdianl study of the holiday appropriation process 


\begin{abstract}
$\underline{\text { Abstract }}$
The tourist experience has been the object of attention for some years yet how the experience unfolds remains an under-researched area. Despite the often exotic setting in which tourism consumption takes place away from individuals' daily life, tourism remains in reality an area of consumption that uniquely mixes both mundane and extraordinary components. Mundane rituals and habits are perhaps less desirable topics of investigation and as a result they have been under-researched, despite the fact that they constitute an important component of tourists' holiday experiences. Rituals can be analysed by using the concept of appropriation that investigates how consumers anchor themselves and develop competencies to adapt in a new experience setting. The appropriation concept has not been applied in a tourism setting and this first attempt aims to understand what it implies in this context. The appropriation process is composed of three steps: nesting, investigating and stamping (Carù and Cova, 2006). A longitudinal study conducted by in-depth interviews everyday of a one-week tourist stay at a ski resort details how consumers develop strategies to nest a temporary home and investigate their new territory. The results point to the importance and interplay of the appropriation phases, how they collectively contribute to the experience, and how resort managers can develop specific strategies to facilitate appropriation. It also investigates to which extent the appropriation model can be adapted to the tourism consumption context.
\end{abstract}

\title{
$\underline{\text { Introduction }}$
}

Tourism has primarily been analysed as consumers seeking to get away from everyday life: a need to escape from the burdens and stresses of contemporary living, pressures from the work environment, and from society in general. Over the years, the mass production of tourism has led to an industrialisation of service provision and, though the spirit of traveling still exists, many forms of tourism keep consumers enclosed in tourists' enclaves.

Whichever way one looks at tourism consumption, it will always remain an extraordinary period, precisely because it is set outside the ordinary life of individuals. Beyond daily life, travel also means escaping social norms and the notion of liminality and the liminoid state capture this temporary disconnectivity (Pritchard and Morgan, 2006; Van Gennep, 1981 (1908) and Turner, 1978). Within liminality, Urry (1990) suggests that consumers cast aside their obligations and move away from rational decisions and behaviour; and then develop a 
new and temporal identify that is different from what characterises their everyday life (socially and work wise).

Despite the extraordinary tourism dimensions and the need to get away from home, mundane rituals still take place on a daily basis, yet without breaking the overall magic of the holiday. Larsen (2008) invites researchers to consider the everydayness of tourism, and investigates the very fact that, while on holidays, consumers need to recreate an alternative home: "further studies should pay attention to the fabric of everyday practices or real holiday experiences to obtain a better idea of what tourists do when vacationing, and how it both ties into and occasionally departs from the lived everyday life at home" (page 31). Rojek and Urry (1997) also indicate that "how we pattern tourist experience and what rules we use when we engage in "escape" activity are much more important than is generally recognized" (Page 55).

These patterns can be addressed through the study of consumers' practices which refers to a dialectic between social structure and human agency. Social practices are defined as routines: "routines of moving the body, of understanding and wanting, of using things, interconnected in a practice" (Reckwitz, 2002, page 255). In 1984, De Certeau produced an interesting work on The Practice of Everyday Life demonstrating the ways in which individuals re-appropriate, in everyday life situations, the dimensions of social life (traditions, language, symbols, and articles of exchange).

Among practices, some are totally mundane and relate to tourists' daily lives and these don't represent the most exciting side of tourism consumption. As a result, they have been the object of less research attention: "Tourism is frequently construed as unusual and extraordinary in contrast to the routines and predictability of work and home life. However, the tourism spaces are co-created through practices that are simultaneously mundane and unusual. Yet everyday touristic practices are seldom researched" (Kaaristo and Rhoden, 2016, page 1). In 2016, De Souza Bispo encouraged researchers to "understand tourism as a set of organizing practices" (page 174) and stated clearly that tourism practices could not be understood in isolation from "non-tourism" practices. In other words, these studies point to the need to consider that, beyond the extraordinary dimension of tourism consumption, mundane and daily routines permeate, and are necessary for tourists to anchor themselves in their temporary and new holiday universe.

In order to understand the complexity of routines, the concept of appropriation is particularly useful and brings a structured framework through which practices can be better understood. 
The concept has only been used to investigate cinema attendance or classical music concerts. Yet, it can be particularly useful to understand how and to what extent travellers need appropriation skills to anchor themselves in their new holiday universe.

\section{1 - The appropriation process}

Appropriation was first identified by Fisher (1992), and more recently redeveloped by Carù and Cova (2006). The concept sets the basis to understand the skills that consumers need to appropriate themselves a new experience universe. The concept of appropriation is tied to the notion of immersion: "The immersion concept literally implies becoming one with the experience and therefore conveys the idea of a total elimination of the distance between consumers and the situation; the former being plunged in a thematised and secure spatial enclave where they can let themselves go" (Carù and Cova, 2003, p. 5). Immersion equates then a plunge into the consumption universe and the feeling of being "in the place" (Sherry, 1998). However, Carù and Cova (2006) argue that this plunge is not systematic and might not spontaneously occur since some experiences fail to immerse consumers. The distance between the experience and the consumer is reduced through appropriation operations in order to personalize it (Ladwein, 2002). The whole process can be summarised as consumers developing a multidimensional 'chez soi' (Carù and Cova, 2006) and developing competencies to co-create their experience with the providers (Holt, 1995). "These operations of appropriation are the mark of a fundamental psychological system of action on the context of the experience in order to transform and personalise it." (Carù and Cova, 2006, p.6). In tourism, the notion of reducing distances echoes Jafari's tourist model (1987) where tourists' emancipation involves two stages: the need to distance oneself from daily life and also to reduce the distance with what is non-ordinary (the holiday context).

In their study, Carù and Cova conducted an analysis of consumers attending a classical music concert in Milano. The consumers surveyed had no previous experiences of those concerts. In the first part of the concert, the maestro, dressed casually, interacted with the public, explained the music piece' story and gave indications about some specific instruments. After the interval, the maestro came back dressed formally, turned his back to the public and engaged his orchestra with no explanations whatsoever. Carù and Cova investigated how consumers reacted to those two different experiences and which elements encouraged or deterred their appropriation process with the concert. Through this study, Carù and Cova 
(2006) identified three appropriation steps: (i) nesting (recreating home); (ii) investigating (exploring surrounding space); and, (iii) stamping (making sense of a place).

Very few studies using the appropriation process exist in tourism despite the relevance of this concept to this setting. Jansson (2007) identified three similar realms through which the tourist experience is produced: scripting, navigation, and representation. Scripting is described as a "referential framework for the planning of a trip" and a "script for how to perform and perhaps reconfigure their own identities within the desired setting" (page 11). Navigation represents the need for tourists to appropriate their new space in order to find sites and connect with social gatherings. Representation translates how tourists immediately share their multi-sensorial holiday experience through new media. Though appropriation as such has not been well developed in the tourism field, some work associated to the concepts of nesting and investigating can bring a rich understanding of those concepts.

\section{Nesting}

Nesting refers to the human need to feel "at home" in new situations: "the individual feels at home because part of the experience being faced has been isolated, a part that is already familiar because of one's accumulated experience and existing foothold in it" (Carù and Cova, 2006). Nesting equals a search for and identification of anchorage points and can be experienced through physical and mental sensations. In Carù and Cova's study (2006), the referents given by a Maestro in his introduction to a classical music concert helped consumers identify points of anchorage.

Essential to nesting is a feeling of home: "Integral to the average everyday life is awareness of a fixed point in space, a firm position from which we "proceed" (whether every day or over larger periods of time) and to which we return in due course. This firm position is what we call home" (in Larsen, 2008, page 24). Home is a liberating place where one feels a friendly atmosphere, freedom to be, restored, a space that one controls and where privacy can exist (Seamon, 1979), independently from home ownership (Windsong, 2010). Dupuis and Thorns (1998) argue that ontological security (the need to be protected from the insecurities of the contemporary world) is maintained when "Home is a site of constancy in the social and material environment; home is a spatial context in which the day to day routines of humane existence are performed; home is a site where people feel most in control of their lives 
because they feel free from surveillance...; home is a secure base around which identities are constructed." (p. 29).

The notion of homeliness connects with Pearce and Caltabiano's (1983) and Maslow's (1943) primary needs for safety and security. Tourists, in a new holiday universe, will be brought back to the basic necessities of their life, verging on survival skills. So the notion of putting close family and friends in a safe context is essential: providing shelter, food, water and security are likely to come forward as prime necessities of a tourist stay and constitute the basic elements to recreate a safe, private and comfortable home environment. No matter how modern and well equipped a resort might be, tourists will experience those feelings. Within this new home, "grounded routines" such as daily activities (sleeping, eating, cleaning..), will make space "homely" (Edensor, 2007, page 206).

\section{Investigating}

Investigating refers to any action that, from the nest, will see consumers exploring physically and identify other products/services that will create new points of anchorage and control called "signposts" (Carù and Cova, 2006, page 7). This process involves observing, describing and exploring and by doing so, consumers will feel more comfortable because they have extended their territory. In Carù and Cova's study (2006) the consumers mention that the Maestro's directions given before the concert, helps them to "find their way" through the concert by being able to understand which sounds come from which instruments and what they refer to in the music storyline.

Investigating is referenced under the concept of "navigation" by Jansson (2007), who stresses the need for tourists to appropriate a new space and to establish "routinized patterns of mobility" (page 12). For Jansson (2007), this step also helps tourists connect with social gatherings, aided by guides, maps, or mobile applications. In 2000, Ingold and Kurtilla conceptualised taskscapes as: a space that is familiar and reproduces everyday life and unreflexive habits, reproduced through mobilities. Mobilities are conceived as a behavioural element influenced by cognitive and subjective decisions and motivations (Tussyadiah and Zach, 2012). Spatiotemporal behaviour has been the object of various research, especially among geographers and planners and both space and time are considered as resources (Grinderberg, Shoval and McKercher, 2014). Connections have also been made between the tourist environment and the quality of experience. O'Dell and Billing (2005) call the spaces 
where experiences are staged and consumed experience-scapes. Evidence shows that all the sensory aspects of a destination are important in the process of facilitating positive tourist experiences. Sensory stimuli (visual, aural, olfactory, gustatory and tactile) help shape the experience scape, and are key to co-creating customer value.

\section{Stamping}

The third step refers to the necessity for consumers to assign a personal meaning to the experience, or part thereof. In Carù and Cova's study, stamping refers to the personal and imaginative meaning that consumers will attribute to an experience, based on their preconceived image and personal experience with similar products (i.e. consumers made parallels with previous concerts, even if they were not classical music concerts).

The stamping phase can facilitate the alignment of fantasy and reality (Schouten \& McAlexander, 2007), the merging of one's inside and outside worlds, and shape personal experiences through creation of memorable moments. This dimension refers to individuals' personal expectations from their holiday and might be achieved as much through the choice of specific activities, as through the choice of companionship and associated bonding expectations. While stamping was fairly easily identifiable in Carù and Cova's study (2006) due to the limited field studied (a classical music concert), in terms of tourism consumption, this step could open up to a vast array of elements associated to tourists' motivations and goals. Moreover, high level experiences have frequently been studied in adventure/wilderness settings (Faullant, Matzlerk and Mouradian, 2011; Pomfret, 2006, 2011), such as in mountain tourism, demonstrating a large array of motivations and expectations.

\section{The interrelations between the three appropriation phases}

Carù and Cova (2006) indicate that the nesting actions are most important, followed by investigation and lastly (and less necessarily) by stamping. The absence of points of anchorage precludes nesting. Carù and Cova (2006) stipulate that marketing can contribute most to the experience in the investigation phase, where consumers clearly need an accompanying process. In contrast, the authors identify stamping as the phase where it is more difficult for marketing actions to intervene because it involves the imaginative process 
individually developed by consumers from the servicescape.

They conclude that among the three phases, circles exist and if nesting comes first, consumers will move back and forward between the phases, particularly if facilitated by the provider. In his study, Jansson (2007) also notes that the three phases (scripting, navigation and representation) are not necessarily sequential but interrelated.

\section{Study Objectives}

To date the appropriation process has only been studied in detail by Carù and Cova (2006) in a short-term cultural experience. The present study aims to adapt this framework to a whole holiday stay. Tourism experience research typically investigates attitudes and beliefs; this study focuses on behavioural practices and rituals to understand the process of appropriation over a long period of time (though attitudes also emerge through behaviour).

The objective of this study is to analyse rituals and practices using the concept of appropriation to investigate and understand how travellers adapt in a holiday setting. It aims to investigate if:

- The appropriation model can be adapted over a longer period of time in a holiday context

- While on holidays, daily routines permeate and become part of the holiday experience construction

- Appropriation steps take place over different days of the week-stay

- Appropriation steps can be facilitated or inhibited through various components under managerial control

\section{3 - Methodology}

Considering the objectives of the study, the researchers opted for an interpretative approach aiming to uncover the meaning in the consumers' description of their experiences. The 
researchers embraced a phenomenological approach to "determine what an experience means for the persons who have had the experience and are able to provide a comprehensive description of it. From the individual descriptions, general and universal meanings are derived, other words the essence of structures of the experience" (Moutsakas, 1994, page 13). In other words phenomenology investigates lived experiences and the consciousness of it (Laverty, 2003) and the hermeneutic dimension identifies the intention and meaning behind the experience studied (Moutsakas, 1994). With the hermeneutic phenomenology approach, Heidegger (1962) emphasised the importance of studying consumers as being in the world (rather than knowing the world). "Hermeneutics moves beyond the description or core concepts of the experience and seeks meanings that are embedded in everyday occurrences and seeks meaning that are embedded in everyday experiences" (Reiners, 2012, page 1). Hermeneutic phenomenology presupposes that any previous experience the researcher has had with the experience must be bracketed out. Whilst this might be easier when studying texts (Creswell, 1998; Laing \& Frost, 2017), in this case researchers had to consciously put aside their own experience with ski resorts.

This research cannot be qualified as grounded research (Matteucci and Gnoth, 2017) since it uses an existing conceptual framework and aims to redeploy it in a different context The approach used in this research is both deductive and inductive: using the general appropriation framework as a guide (Carù and Cova, 2006) and then identifying its three steps, in a tourism context, from the data collected.

To investigate the evolution and interplay between the steps during the holiday, interviews were conducted every day of the consumers' stay. Such a longitudinal approach is rare in tourism research, and very rich at understanding how experiences develop and evolve during a stay (De Bloom, Geurts and Lohmann, 2017; Ingram, Caruana and McCabe, 2017; Nawijn, 2010; Pearce, 1981).

Experiences are often researched after they take place and a vast range of information gets lost with this investigation process (Tussyadiah, 2014). Furthermore, because the study was investigating some mundane actions undertaken by tourists, those had to be explored on the day they happened (it was unlikely that tourists would remember them in detail after the experience). To overcome these gaps and develop a rich data corpus, tourists were interviewed, every day, at the heart of their consumption: « an analysis of what tourists are doing when they are being tourists or talking about their behaviour can provide a unique insight into the everyday lifeworlds of members of society » (McCabe, 2002, Page 63). 


\section{Interview guide}

Since the study investigates practices developed by consumers from a very personal perspective, other elements pertaining to the destination resources were not specifically investigated (local culture, theming, natural context, etc.). The interview concentrated on the nesting and investigation actions and the meaning attached to them (stamping). The praxeologic vision was essential here: understanding the actions undertaken by tourists and the meaning attached to them.

Since the concepts involved were touching mundane and yet personal elements, the interview technique was seen as the most appropriate method to collect data within the intimacy of the group. In many ways the interview process resembled a conversation encouraging participants to detail how each day unfolded. Conversations have been described as a powerful tool to get into the intimacy of consumers' experiences (Ryan, 1995; Blommaert and Jie, 2010) and this approach was particularly useful in this study.

The interview guides included questions investigating in depth the concepts of nesting, investigating and stamping. After a description of their day, participants were asked to detail how they organised themselves in and around their rented accommodation: how the group dynamics unfolded, the different organising elements, how they perceived this organisation, the different timings taking place in the group, etc. Investigating was addressed through a description of their arrival: how they reached the resort, how they orientated themselves upon arrival, how they found their accommodation, etc. Then investigative questioning was undertaken every day at two levels: depth of resort and slopes' exploration, willingness/or not to investigate, etc. For both these steps, it was essential to identify contributors and inhibitors in order to provide in fine managerial implications. Stamping was the last phase investigated and the meaning associated to the practices was identified by questioning consumers to elaborate on their personal meaning for the different practices they described.

Half way through the week, half of the sample was given more information from interviewers regarding investigation possibilities: the interviewers gave some inside information to half of the group investigated, indicating slopes that were more pleasurable in the morning/afternoon, 
and encouraging them to explore the Orelle area (typically an area most consumers don't explore). This was an attempt to reproduce Carù and Cova's study although in reverse. In their study, the Maestro only gave explanations to the public in the first half of the concert. In this study, researchers let people appreciate their holiday context in the first place, then gave them some specific information to encourage slope and resort investigation in the second half of the week.

\section{Data analysis}

All the interviews were recorded then transcribed. Making sense of such a vast amount of data was challenging and required a strategy. Creswell (1998) indicates that: "Phenomenological data analysis proceeds through the methodology of reduction, the analysis of specific statements and themes, and a search for all possible meanings" (page 52). IN this line of thought, thematic analysis provides a flexible and useful structure to undertake this analysis. Braun and Clarke (2006, page 87) identify five steps to undertake thematic analysis: familiarisation with the data, generating initial codes, searching for themes, reviewing themes, and defining and naming themes.

(i) Familiarisation with the data: First, the researchers read all the data corpus of the 16 interviews in order to gain familiarisation with the data. In process, the researchers noted down ideas about the three steps and questions that emerged from their reading.

(ii) Generating initial codes Then the three researchers shared the 16 interviews between them and identified separately initial codes across the corpus studied. Each author determined a list of codes relating to elements describing the nesting, investigating and stamping phases.

(iii) Searching for themes: researchers shared and discussed their results to identify the key themes that were characteristic of each phase. This step was rather long but necessary to identify which elements composed the three appropriation steps on a week-long holiday context. This phase was most probably the most difficult one since the context studied was so different from the original study. At this stage, the consumers used the original three dimensions produced by Carù and Cova and focused their efforts in identifying which practices/meaning belonged to nesting, investigating and stamping. For instance investigating had to be subdivided into two different dimensions. 
(iv) Reviewing themes: the researchers identified different elements as constituting the three appropriation phases. Because the context was different from Carù and Cova's study, the construction of a thematic map was useful (Braun and Clark, 2006) (Figure 1).

(v) Naming themes: They decided to keep the same names as they were representative of the elements observed.

Figure 1 - Thematic maps produced in step 4 of the data analysis
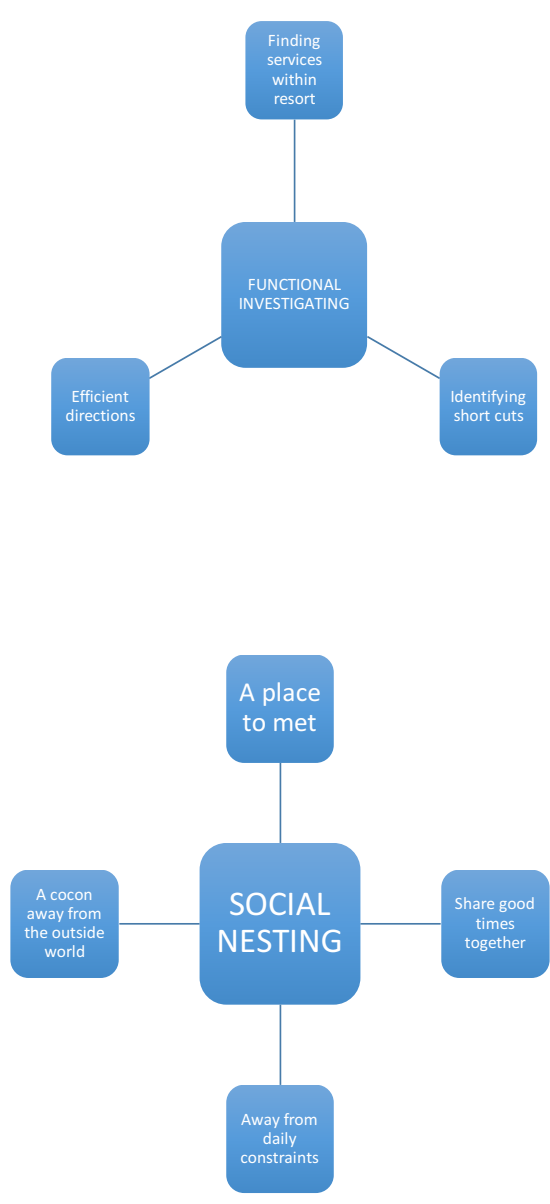

\section{Study context}


The study took place in a ski resort, a setting pertinent to the research project since tourists typically spend a week and stay at the resort the entire time, allowing for the appropriation process to occur in a limited physical setting. The ski resort, Val Thorens, was built in 1972 and is located in the Savoie region (France) at 2300 meters high, giving access to the largest ski area in the world. Even though the resort is fairly big, the village itself is organized in a circle shape, making it possible to explore it by foot. The sample of tourists interviewed were recruited on the Facebook website of the resort, inviting tourists to take part to a study in exchange for unspecified rewards. Among the 31 positive replies received, 18 were selected at random (flat owners were excluded as they had a different relationship with the resort), and in the end 16 groups of consumers participated ( 2 groups withdrew on the spot). The interviews took place daily, Sunday to Thursday, late afternoon in February 2015. Participants were not interviewed on their arrival day; this Day 1 was described in revert the following day when the first interview took place (on Day 2 - Sunday); then interviews took place till day 6 (Thursday). People were not interviewed on the last day (Friday) as they were packing, leaving early the following morning. Eight trained interviewers collected the data, since consumers could only be interviewed after their day activity, the interviewing window was rather small (5 pm to $8 \mathrm{pm}$ ). Each interview lasted between 40 minutes to one hour. None of the 16 consumer groups were traveling alone, and as the interviews took place, other members of the group intervened. In the end, 86 people participated to the study.

Table 1: Profile of Study Participants

\begin{tabular}{|c|c|c|c|c|c|}
\hline $\begin{array}{l}\text { Name of } \\
\text { interviewe } \\
\text { e(s) }\end{array}$ & Age & $\begin{array}{l}\text { Country } \\
\text { of origin }\end{array}$ & $\begin{array}{l}\text { Professio } \\
\text { n }\end{array}$ & Group composition & $\begin{array}{l}\text { Total number } \\
\text { of persons in } \\
\text { the group }\end{array}$ \\
\hline $\begin{array}{l}\text { Charlotte } \\
\text { Helen }\end{array}$ & 42 & France & $\begin{array}{l}\text { Executive } \\
\text { in the food } \\
\text { sector }\end{array}$ & $\begin{array}{l}\text { Two families with four } \\
\text { children }\end{array}$ & 8 \\
\hline $\begin{array}{l}\text { Hen \& } \\
\text { Ralph }\end{array}$ & $56 \& 28$ & Holland & $\begin{array}{l}\text { Optician/ } \\
\text { Marketing } \\
\text { manager }\end{array}$ & $\begin{array}{l}\text { Three generations of } \\
\text { the same family, } \\
\text { separate flats }\end{array}$ & 15 \\
\hline $\begin{array}{l}\text { Maren and } \\
\text { Chris }\end{array}$ & $30 \& 40$ & $\begin{array}{l}\text { Canada } \\
\& \text { UK }\end{array}$ & $\begin{array}{l}\text { School } \\
\text { teacher / } \\
\text { IT }\end{array}$ & Couple & 2 \\
\hline $\begin{array}{l}\text { Patricia et } \\
\text { Marc }\end{array}$ & 60 & France & Teachers & $\begin{array}{l}\text { As a couple with their } \\
30 \text { years' old son }\end{array}$ & 3 \\
\hline
\end{tabular}




\begin{tabular}{|c|c|c|c|c|c|}
\hline Françoise & 55 ans & France & Executive & $\begin{array}{l}\text { With a friend couple } \\
\text { and their grand- } \\
\text { daughter }\end{array}$ & 3 \\
\hline $\begin{array}{l}\text { Gert et } \\
\text { Sigrid }\end{array}$ & $46 \& 48$ & Belgium & Manager & $\begin{array}{l}\text { Two couples with their } \\
\text { children }\end{array}$ & 8 \\
\hline Nick & 40’s & UK & executive & $\begin{array}{l}\text { On his own with his } \\
\text { two sons }\end{array}$ & 3 \\
\hline Dominique & 36 & France & $\begin{array}{l}\text { Military } \\
\text { Officer }\end{array}$ & $\begin{array}{l}\text { A couple with } 3 \\
\text { children }\end{array}$ & 5 \\
\hline Christiane & 72 ans & France & Retired & $\begin{array}{l}\text { Couple with their eldest } \\
\text { son ( } 40) \text { and two grand- } \\
\text { children }\end{array}$ & 5 \\
\hline $\begin{array}{l}\text { Steve \& } \\
\text { Chris }\end{array}$ & 38 & UK & $\begin{array}{l}\text { Schoool } \\
\text { teachers }\end{array}$ & Male friends & 2 \\
\hline Kate & 44 & Ireland & $\begin{array}{l}\text { Language } \\
\text { teacher }\end{array}$ & Couple +2 sons & 4 \\
\hline Fergus & 46 & Ireland & Executive & $\begin{array}{l}\text { Four dads and } 9 \\
\text { children }\end{array}$ & 13 \\
\hline $\begin{array}{l}\text { Gege and } \\
\text { Claire }\end{array}$ & $47 \& 45$ & France & Nurses & Two families & 9 \\
\hline Géraldine & 36 & France & IT analyst & $\begin{array}{l}\text { Mother of two with } \\
\text { another family-group of } \\
\text { friends }\end{array}$ & 8 \\
\hline Darras & 43 & France & Executive & $\begin{array}{l}\text { Couple with three } \\
\text { children }\end{array}$ & 5 \\
\hline Barnier & 44 & France & Executive & $\begin{array}{l}\text { Couple with three } \\
\text { children }\end{array}$ & 5 \\
\hline
\end{tabular}

\section{4 - RESULTS}

\section{Nesting - Organising the new home}

Nesting comes up as a very strong element right upon arrival. The first step after finding the accommodation location is to physically settle: take note of the apartment facilities, allocate rooms and unpack. This first step requires condensed and intense organisation and it is interesting to note that most participants, if they came by car, had already prepared for a smooth arrival, especially in terms of food preparation. Most had purchased groceries in the valley and a third of the French visitors had brought dishes they had cooked at home to save preparation time at the resort (even allocating different dishes between members and days). "I 
have the beds made because I had all the linen, I have done the shop, I got the tickets from the lift pass machine, done the shopping and cooking... » (Kate on Day 2).

The functional aspect of settling also referred to allocating roles among members and finding the group's rhythm. This rhythm is not instantaneous and will take two to three days to really settle as a group dynamic: "On the first morning, it was difficult, we were all together, bathroom, breakfast, now it is fine, we got the rhythm, we have got ourselves organised then we will leave soon but such is life" (Gégé, Day 3)

This part of nesting calls for organisational skills (often gained through previous travel experiences), and refers to the need to set a convenient frame so that the rest of the week runs smoothly. Allocating responsibilities between group members is also a way to reinforce groups' cohesion and transfer competencies, especially to younger ones: "It's important that they (the children) learn that they have to do things as well and they have to keep the place clean and they go and carry, share the work." (Fergus on Day 3)

This step is not necessarily seen as a burden: it is very much part of the holiday and if correctly mastered, it allows the group to be fully available for what matters most - a week stay in a mountain resort.

Once the basic elements of nesting have been mastered, from day 2 or 3 , the groups enter a form of organisational routine perpetuated throughout the holiday without even thinking about it: buying croissants and fresh bread in the morning, going to the market, preparing food, taking turns in the bathroom, cleaning...

However, looking after one's home is perceived differently in a holiday context, and consumers simplify their daily home routines: "Usually I am quite a maniac type of person, but here I don't get worked up about things, I do the minimum. Since this is not my house from a cleaning point of view, I do the minimum. I don't sweep the floor, morning lunch and evening, and because I am on holidays I don't cook as intensely as when I am at home, I don't get worked up about things." (Géraldine, Day 2)

On rarer occasions, the holiday offers the possibility to redevelop a long lost family role due to daily time constraints: "I prepare meals, this is what is nice. During the year, I never have the time to prepare meals. Here I don't ski in the morning, I go shopping for groceries, and when they (husband and two sons) arrive at lunchtime, everything is ready, this is such a nice side to the holiday, I like to please them this way" (Barnier mother - Day3). 


\section{Inhibitors to organising the new home}

Several elements were identified that could be detrimental to the notion of feeling at home. A good home is perceived as a safe environment where one can enjoy quality time and quality rest. As a result, noise disruptions are negatively perceived since they are detrimental to a restful sleep: “We were woken up three or four times last night with singing and shouting in the street. Then in the morning a truck delivered food under our window in the first hours, then the snow cannons took over. As a result, everyone in the family felt very tired and grumpy, and the following day we only skied for a half-day." (Kate, Day 4)

In fact, noise was a problem for most consumers, the buildings are on a central heating system that tends to overheat accommodation, therefore consumers tend to sleep windows opened which necessarily lets outside noise in.

Most rented flats have basic cooking facilities and most groups felt that they could not cook properly, especially for big groups (small ovens, under-heating cookers, etc.).

The other identified disruptive aspect was associated to the bathroom. Two groups experienced either a lack of hot water or a broken shower. After a day skiing, not being able to take a proper shower is simply inconceivable: "The low moment the shower! That was a low moment. "(Steve and Nick, Day 5).

\section{$\underline{2 \text { - Investigating }}$}

First, investigating is a skill that is solicited upon arrival (Day 1): finding the apartment, parking the car to unload, identifying the underground car park, are the first necessary steps. Road signage proved quite useful especially since consumers arrive late in the day after a long trip.

Once consumers have settled into their accommodation, from day 1 onwards, they gradually venture from their nesting base to discover the resort itself, and then the slopes.

\section{Investigating the resort}

For a third of the sample, once they have found their accommodation, there is an urgent need to explore the resort on Day 2 : "I need to locate the scene, I start walking, see the shops, understand where are the slopes access, the restaurants, the parking... it is there, to the 
North. I need this recognition straight away. I am used to do it every time I arrive in a resort, so I tend to do it quickly." (Barnier, Day 2)

What is surprising throughout the study is the haphazard way in which visitors discover the resort: they venture, sometimes ask for information, struggle to find local people with "inside knowledge", and in the end they learn through their mistakes (or they don't find the services at all). They often get help from other tourists, which interestingly, creates social connections. Investigating the resort is usually undertaken on day 1 and it takes tourists about three days to find their way around the resort (it took one participant more than three days to locate a handy bus-stop). They identify shortcuts only towards the end of their stay (hence losing a lot of time during the week). Consumers tend to look for facilities close to their apartments, overall they don't venture very far: once they have found what they were seeking, they don't venture further. Since the main focus of the holiday is skiing, the necessities within the resort itself are fairly limited to the most basic functional services: a supermarket, a baker, a rental ski shop, the information centre (but not systematically) and a bar/restaurant. A gender difference can be clearly identified: women tend to orientate themselves quickly by going to the tourist information centre to get maps, whereas men are more relaxed about finding their own way. Repeat visitors explore very little of the resort, they use the signpost they placed during their previous holiday and make no real attempts to investigate beyond.

Consumers appreciate having all the amenities at hand: it is more convenient and creates atmosphere: «Shops, bars, supermarket. Everything. In fact I like being in the centre of a town. It's more atmospheric." (Steve and Chris).

\section{Investigating the slopes}

If people stay within Val Thorens it eases their skiers' life as it is shaped like a cuvette: "In Val Thorens, all roads lead to Rome. You can let yourself go, you won't loose your day because you made a mistake." (Chirstiane's husband). However, exploring the Trois Vallées domain is more complex since it is the largest ski area in the world with 600 Kilometres of slopes unifying the three valleys of Méribel, Les Ménuires and Courchevel. Within this vast domain, it can take a long time for skiers to go from one valley to the next, and find their way back before the lifts close. 
When skiers start to venture to the other valleys, then it gets more complicated, because they get lost or take longer roads to return. Using maps tends to be tricky; the hands get cold, one needs to put on glasses, so they use mostly the directional signs on the slopes. Skiers tend to explore in a haphazard way, they follow signs, not always identifying the most efficient routes. Here again, inside information from other tourists can come useful: "Well, when we were coming back from Méribel, yesterday, it took us a long time; it took us nearly an hour and a half. Today it took us 30-40 minutes because we got directions from a friend we were visiting and who is living in Courchevel and he knew, so he gave us exact directions and it was much easier." (Fergus)

Because the resort is vast, the need for exploring is not vital at first (also most tourists have not skied for a year and are keen to get on the slopes, regardless). From day 4 however, they are keen to see more and then start venturing to other slopes, but the process remains fairly haphazard: "We started to get bored with the slopes we had been doing, so we forced ourselves to go down different slopes, and in the end when you do such nice rides, every time it is sheer pleasure. We could vary our skiing." (Gert on Day 4)

For the group of visitors who received new directions half-way through the week, this proved to be a real experience booster: "I am so pleased that you indicated Orelle, I am so happy to have seen this! It gave me a boost. It was excellent. I might have not gone there or not so soon. And in the morning there were less skiers so we really enjoyed it, wonderful!" (Negroni). It is clear that this information was given at the right moment, earlier in the week consumers would have been too keen to ski to need to find new areas, yet.

\section{Investigating inhibitors}

The perception of being free to investigate is tempered by the level of the skier. For inexperienced skiers, there is always the fear of ending up on a difficult slope that one might not manage. Generally speaking, participants did not feel that the slopes were well signed and tended to get lost: "Yeah, it's not as easy to follow where you're trying to go. There are lots of runs that change into another run and it's like you have to remember sort of your sequence. » (Chris and Maren)

Not being able to investigate and locate oneself properly on the slopes is a real source of stress if parents need to be back at a specific time to pick up their children from ski schools 
(the schools do not have indoor spaces to drop the children). This stress diminishes their enjoyment of the ski experience and the scope of their investigations (they don't venture as far as they could). The same stress emerges towards the end of the day when the lifts are about to close: «I'm not good at orienteering! a map in the gondola would be nice, it would make it easier to find one's way. My husband is guiding us but he doesn't like it, with the idea of getting stuck. And clocks everywhere! putting clocks at the top of ski lifts. After 4pm I'm worried not to have enough time to come back. » (Charlotte on Day 3)

\section{$\underline{\text { 3-Stamping }}$}

Stamping refers to the personal meaning consumers develop from their experience. Bonding is the element that stood out most in all participants' testimonies: the holiday takes on the importance of being a refresher course in what families and friendships life is all about: make time available to be together, share conversations and share time together. This communion can take place within the home or outside, through activities.

\section{Bonding “at home"}

Group togetherness, when it involves a skilled activity, encourages participants to group according to their respective levels. Even though the whole group is longing for togetherness, it will only achieve this at certain periods of the day. For example, groups have breakfast together and usually meet at lunchtime either on the slopes or at their flat. They might split the day (children taking lessons in the morning then skiing with their parents in the afternoon), and skiers and non-skiers involved in different activities throughout the day will meet at night. Skiers with different levels may ski together for a while and then split for the rest of the day. Whatever the case, once the ski day is over, there is an important time to get back together and share stories. The home becomes a communion place where quality bonding and sharing takes place.

The home setting, in the evening, becomes the ultimate sanctuary for family ties. Strategies are then developed to encourage these strong moments, for instance, families will play card games rather than each member being hooked on their own screen. The majority of consumers interviewed voluntarily did not switch on the TV, nor accessed Internet to allow for a quality bonding time to take place. The time spent together in the evening is also very precious because of availability (i.e. no homework for the children, parents "are home" early, skiers/non-skiers meet again): "During the day we do meet some people, but it is only 
punctual. In the evening it's only us, it's our thing, the cocoon, this is where the five of us get together, and in this sense this is why those holidays are so privileged." (Barnier - two parents and their three children).

Sometimes, this quality time might be "forced" by the lack of Internet connectivity: «I think not having Wi-Fi is really, really... it's like detached because we can't post and we can't talk to our family but it's also quite nice as well. I'm not getting disruptions from emails or tweets or Facebook or anything. » (Chris and Maren - a couple).

An interesting point was the incapacity that one group felt to be "at home" because the owner of the flat had left personal pictures of his children on the walls: the group felt that they were clearly in someone else's flat (and life) and found it more difficult to nest.

\section{Bonding through activities}

Bonding is highly valued and priceless in a world where day to day life seems to leave little time for those interactions and even more so when children are growing up: "Children grow fast unfortunately, and they become adolescents. They become more introvert, speak less, sometimes 4 to 5 months happen without knowing what is happening in their lives. (...) So, that's been nice to just catch up and understand what's going on in his life and what are the things that interest him. So, that's been great." (Nick - talking about his son).

Skiing is clearly identified as one of the few activities that parents can share with their children. Whilst they cannot share hip-hop or skateboard sessions, parents have often learnt skiing in their youth and can be at an equal level of competence with their children (and even teach them). These special moments during skiing and on the chair lift become strong bonding times: "I feel that I have talked more with my son in the two hours we did skiing together yesterday than in the whole previous year". (Juan). Or Nick, a busy dad who feels that he does not have much time to see his sons: "It is a great opportunity for us to bond. We talk about things we don't normally talk about."

\section{4 - Interplay between nesting, investigating and stamping}

In terms of timing, both the nesting and investigation phases are characteristic of the first days of the holiday: "We have now achieved a total deconnection, we are away from the real 
world. For the first three days we were still involved in the organisation of the holiday, we discovered gradually the resort, and today we are more settled, more stable."(Darras on Day 3)

The dynamics confirm Carù and Cova's study: nesting is the first most important phase, followed by investigating, however consumers did not necessarily move back and forth between phases. The results from this study tend to indicate that the two phases exist in parallel all along the holiday and with decreasing strength (nesting) and recurring strength (investigating).

There is a clear threshold point around day 3, once the nesting operations have taken place and consumers find their way around the resort: "One important thing I have noticed, and because it is the third day, we always say hello when we meet people, people become civilised again. Even yesterday, a tourist asked me if I minded him sitting next to me on a bench. So I think, because it is the third day, people relax. Today, some foreign tourists nodded their head at me, I felt that this changed compared to the beginning of the holiday." (Christiane, day 3).

From Day 3 onwards there is also a renewed interest in investigating, not the resort but the slope, in search for new exciting experiences.

If mundane and daily duties remain, they will be reduced to a strict minimum to become a holiday routine by day 3 , and consumers can then devote most of their attention to the coregoals of their holiday: practicing their activities and sharing time together.

\begin{tabular}{|c|c|}
\hline PHASE & Days \\
\hline NESTING & 1 to 3 then becomes a routine \\
\hline $\begin{array}{l}\text { INVESTIGATING } \\
\text { SLOPES }\end{array}$ & $\begin{array}{l}\text { Intense on days } 1 \& 2 \text { then new needs from day } 4 \\
\text { onwards }\end{array}$ \\
\hline $\begin{array}{l}\text { INESTIGATING } \\
\text { RESORT }\end{array}$ & Intense on first few days but generally limited \\
\hline STAMPING & $\begin{array}{l}\text { Increases day by day, it is the driving force behind } \\
\text { it all and is fed through individuals actions and all } \\
\text { other phases contribute to it }\end{array}$ \\
\hline
\end{tabular}

\section{DISCUSSION}

This study presents an adaptation of the appropriation steps of Carù and Cova's model (2006) to a holiday context with a focus on rituals and practices. The longitudinal study is very powerful at identifying how processes fall into place and how tourists organise their new temporary home. 
First of all, mundane habits are very present at first when consumers arrive at a resort, they will need to settle in their new accommodation and make it homey. Inhibitors to setting up the functional home pertain to the basic needs of individuals: whilst issues of security and comfort did not really emerge in this study, problems encountered with noise disruption, cooking and hygiene facilities show how important it is for tourists to feel relaxed and comfortable with the primary necessities of a good home.

However, mundane rituals are redeveloped in a different spirit, echoing Larsen's work: "Tourism is bound up with performing social life and building an alternative "home", a utopian performance where everyday routines, doings and roles hopefully become extraordinary: relaxed, jointed and joyful" (2008, page 28).

Mundane rituals are accepted as long as they fuel the bigger aim of a pleasant, welcoming and warm home where socialisation takes all its importance. This echoes Löfgren's statement that: "Getting away from it all might be an attempt to get it all back to together again" (1999, p. 269 - in Larsen, 2007, page 28). Tourists are not only questing authentic places and objects; they also search for authentic sociability between themselves (Wang, 1999). As a result, beyond the functional home, it is also a place where deep connections and proximity can develop within the family/friends unit. This resonates Larsen and Kirkegaard (2013) identification of family flow that can occur as much through activities than through the simple action of being together. Socialisation can involve changing habits to make sure the time spent together is valuable (switching of TV, playing games, etc.).

Wang's vision (1999) that the alternative home is reconceptualised in a more relaxed manner was evident in this study where tourists clearly showed willingness to less worked-up about things. Hence, rituals are simplified to the most basic levels and tourists engage in a slower pace of variance to the rhythms of life and work (Edensor, 2007, 2010).

The new home is identified in opposition to daily life: elements pertaining to negative routines are removed and rituals that are necessary to nest are maintained while on holidays. For instance, cleaning and cooking are part of daily rituals perpetuated on holidays but elements such as DIY, ironing clothes, in-depth cleaning of the house are absent. There are subtle differences between mundane habits that are made fun and part of the holiday and those that are a reminder of daily and temporarily unwanted lives.

The results indicate that it takes several days for tourists to unwind: it is only from day 3 onwards that tourists show clear signs of detaching themselves from everyday life but also from the functional activities associated to nesting and investigating. This detachment process 
will reinforce itself as tourists progress through the week. This is faster than what other researchers have suggested. In a study of nine Canadian participants visiting Hong-Kong, McKercher \& Lui (2014) identified that this process took five days. In a study of cultural chock on island tourists in Australia, Pearce (1981) identified that negative moods decreased after the third day and was much associated to tourists health problems and the increase of self-initiated activities as the holiday evolved. Whilst cultural chock did not appear to be an issue in this study, one can envisage that self-initiated activities are a reflexion of tourists anchoring themselves more confidently in their holiday, as was noted in this study.

Carr (2002) suggests that the process will take different dynamics depending on the nature and duration of the trip and the degree of psychological separation. Clearly in this study, the holiday setting, the skiing activity highly conductive of flow (Csikszentmihalyi,1991), along with the duration of the trip all contribute to tourists distancing themselves more rapidly than in this context (tourists only come for one week and it is often the only skiing trip they will undertake in a whole year).

Whilst investigating might appear as a more basic step of the holiday process, it is a necessary one because orientation is associated with efficiently maximizing time for valuable experiences. Wasting time, getting lost is as much time not available for more pleasant activities. More importantly, the lack of investigation (and even more so for returning visitors) is very detrimental to the holiday experience simply because tourists fail to identify services, events, skiing areas that could have heightened their experience. Overall the lack of investigation on visitors' behalf (in the resort as much as on the slopes) is detrimental to the depth of their experience.

However, the part of the group that received mid-week information to investigate new slopes showed a clear break in detachment and true enjoyment of their activity. Therefore, whilst investigation appears mostly functional, it is also a mean to an end. In a praxeologic vision, investigation is therefore an important component insofar as it gives access to new discoveries that clearly enlighten visitors' experience. This is especially true when boredom could potentially set in from day 4 onwards and tourists need new boosters to their experience.

Both nesting and investigating have a functional and an experiential dimension. 
Nesting has a strong functional dimension at first and it quickly becomes the centre of attention for bonding and socialisation to take place, leading to social nesting. So home has both dimensions: on one side it has a functional aspect but it is also a key reunion point for togetherness to excel.

Secondly, investigation also has two dimensions: a very functional aspect that is associated to locating oneself and finding useful services; and a more experiential dimension insofar as investigation is what allows tourists to gain access to more fulfilling holiday dimensions: explorative investigation.

This bi-dimensional side of both nesting and investigating was not identified in Carù and Cova's study but echoes recent work by Sørensen and Jensen (2015) on the necessity to integrate both functional and experiential dimensions in service encounters.

Both functional nesting and investigating allow for consumers to set solid basis of a good home and a good holiday situation that then feeds into stamping: once the ideal home is recreated then consumers develop a strong meaning out of the intense sociable time they spend together.

\section{Managerial implications}

Whilst the time spent on nesting and investigating are unavoidable, there are some innovations that resorts could develop to ease this process. The table thereafter presents some of the implications that were drawn from the results, detailing the appropriation step concerned, the difficulty encountered, the managerial improvements suggested and the outcome expected. Whilst some of those elements seem to relate to minor functional improvements, one should always keep in mind that they are related to larger and more meaningful outcomes. Reducing the functional appropriation elements liberates time for the more important experiential dimensions. Whilst some of the elements cited can clearly be the object of managerial improvements, others, such as togetherness especially within the new home, are tied to the intimacy of the group and do not require much marketing interference. 
Nonetheless, the results clearly show that some of the functional home elements will contribute to the togetherness capacities of the group so they should not be disregarded

Table 1 - managerial implications to improve each appropriation step

\begin{tabular}{|c|c|c|c|c|}
\hline $\begin{array}{l}\text { Phase } \\
\text { concerned }\end{array}$ & $\begin{array}{l}\text { Problem } \\
\text { identified }\end{array}$ & $\begin{array}{l}\text { Improvement } \\
\text { suggested }\end{array}$ & Outcome/objective & Timing \\
\hline Nesting & $\begin{array}{l}\text { Providing for } \\
\text { basic needs }\end{array}$ & $\begin{array}{l}\text { Pack of basic groceries } \\
\& \text { pre-rented skis } \\
\text { directly delivered to the } \\
\text { accommodation } \\
\text { Develop a conciergerie } \\
\text { service }\end{array}$ & $\begin{array}{l}\text { Facilitate, accelerate } \\
\text { and simplify the } \\
\text { functional nesting } \\
\text { process } \\
\text { Ease access to } \\
\text { different services }\end{array}$ & $\begin{array}{l}\text { Day } 1 \text { and } \\
\text { after }\end{array}$ \\
\hline Investigating & $\begin{array}{l}\text { Fear to get lost } \\
\text { on the slopes }\end{array}$ & $\begin{array}{l}\text { Resort: produce a } \\
\text { resort-phone } \\
\text { application indicating } \\
\text { key services per } \\
\text { categories (restaurants } \\
\text { shops, entertainment, } \\
\text { etc.). Indicate also } \\
\text { pedestrian distances and } \\
\text { shortcuts within the } \\
\text { resort. } \\
\text { Slopes: interactive } \\
\text { phone application } \\
\text { indicating } \\
\text { connecting skiing times } \\
\text { and closing times per } \\
\text { lift and the most } \\
\text { efficient way to reach }\end{array}$ & $\begin{array}{l}\text { Reduce skiers' stress } \\
\text { of not being back on } \\
\text { time at the resort; } \\
\text { hence improve their } \\
\text { enjoyment of skiing } \\
\text { to the most }\end{array}$ & $\begin{array}{l}\text { Day } 1 \text { and } \\
\text { after }\end{array}$ \\
\hline
\end{tabular}




\begin{tabular}{|c|c|c|c|c|}
\hline & & $\begin{array}{l}\text { the resort. } \\
\text { Indication } \\
\text { commuting time on } \\
\text { slopes (panels } \\
\text { indicating on-time } \\
\text { return times) } \\
\text { Information (mobile } \\
\text { phone push mails/text } \\
\text { messages) to induce } \\
\text { more exploration }\end{array}$ & $\begin{array}{l}\text { Encourage tourists to } \\
\text { venture further away } \\
\text { or to areas they } \\
\text { would not have } \\
\text { thought of } \\
\text { investigating, and at } \\
\text { which times of the } \\
\text { day. }\end{array}$ & $\begin{array}{l}\text { From Day } \\
2\end{array}$ \\
\hline Stamping & $\begin{array}{l}\text { Incapacity for } \\
\text { big groups to } \\
\text { find large-size } \\
\text { accommodation }\end{array}$ & $\begin{array}{l}\text { Identify large flats } \\
\text { within resorts to push } \\
\text { forward through } \\
\text { booking agencies. } \\
\text { Identify flats on the } \\
\text { same landing } \\
\text { Making sure that the } \\
\text { facilities are of a good } \\
\text { quality level: proper } \\
\text { cooking appliances, } \\
\text { hygiene facilities, etc. }\end{array}$ & $\begin{array}{l}\text { Allow groups to be } \\
\text { together by either } \\
\text { staying in the same } \\
\text { accommodation or } \\
\text { identifying flats very } \\
\text { close to each other }\end{array}$ & $\begin{array}{l}\text { Several } \\
\text { months } \\
\text { before the } \\
\text { holiday, } \\
\text { when } \\
\text { booking }\end{array}$ \\
\hline
\end{tabular}

\section{Limitations:}


The results collected in this study have to be interpreted within the limits of the setting of the data collection. As a start, the collection took place during a week with extremely good skiing conditions and exceptional weather. As a result, researchers could not explore how consumers would react if they had not been able to ski. All the consumers investigated were in rented accommodation, therefore looking after their daily needs. The results might not transfer easily to an all-inclusive model.

The consumers were recruited on the resort website and had all booked independently. The tour operators' consumers were therefore excluded from the study, especially younger visitors coming from northern Europe and who tend to have a more party-oriented focus.

Finally, the group of 8 interviewers met with the 16 groups every night of their stay which might have introduced a relationship with the researcher and an impact on their answers.

Lastly, the project investigated the appropriation process to the exclusion of many other related concepts (perception of authenticity and the natural environment were not investigated).

\section{CONCLUSIONS}

This study has identified the three components of the appropriation concept adapted from Carù and Cova's model ((2006) to a multi-day holiday context. Components under managerial control are identified to assist ski resorts as well as other tourism operators.

Due to the specific tourism context, and to the contrary of Carù and Cova's model, the nesting phase is of upmost importance in a holiday context and is a necessary stage of appropriation. Nesting however has two dimensions: setting up a functional home and also a social base where bonding takes place. In parallel, investigating is a crucial component of the experience as it opens the possibilities to enlighten the experience. Here too, two dimensions are observed: functional investigation to find necessities, as well as a more explorative dimension reflecting a sense of discovery.

Whilst nesting and exploration are necessary steps, if they are difficult to manage on tourists' behalf, they will absorb more time of the tourist stay and as a result, tourists will devote less time to the enjoyment of their holiday.

The longitudinal approach developed in this study, demonstrates the richness of the data collected. Moreover, by investigating the day-to-day tourist experience, elements are 
uncovered that give a clear indication of the succession of events to feed the experience and how each step unfolds at different days of the week-stay. To this day, too few longitudinal studies exist and should be encouraged in further studies.

One element that was not investigated in this study is the possibility to boost both nesting and investigating before arrival. Indeed providing necessary advice and information when tourists are packing their suitcases, providing information about specificities of the mountain context are all elements that would assist consumers in developing quicker a homey feeling.

Finally, new technological tools could bring a very useful supplementary analysis to the investigation phase. For instance, the notion of investigation and use of space could be improved by using GPS following tourists' movements. This analysis coupled with the notion of timing could bring a much more precise notion of rhythms that could be extremely valuable.

\section{REFERENCES}

Blommaert J. and JIe D. (2010) Ethnographic fieldwork, Bristaol: Multilingual Matters.

Braun V. and Clarke V. (2006) Using thematic analisys in psychology, Qualitative Research in Psychology, 3: 77-101.

Carù, A., \& Cova, B. (2006). How to facilitate immersion in a concumption experience: appropriation operations and service elements, Journal of Consumer Behaviour, 5: 4-14.

Carù, A., \& Cova, B. (2003) Revisiting consumption experience. A more humble but complete view of the concept, Marketing Theory 3(2): 267-286.

Carr N. (2002) The tourism-leisure behavioural continuum, Annals of Tourism Research, 29(4): 972-986.

Csikszentmihalyi M. (1991), Flow: The Psychology of Optimal Experience, New York: Harper \& Row

Creswell J.W. (1998) Qualitative inquiry and research design, Thousand Oaks: Sage. 
De Bloom J., Geurts S. and Lohmann M. (2017) Tourism and love: how do tourist experiences affect romantic relationships? In: Filep, Laing and Csikszentmihalyi, Positive Tourism, Routledge, pages 35-53.

De Certeau M. (1984) The Practice of Everyday Life. University of California Press, Berkeley.

De S. Bispo M. (2016) Tourism as practice, Annals of Tourism Research, 61(November) : 170-179.

Edensor T. (2007) Mundane mobilities, performances and spaces of tourism, Social \& Cultural Geography, 8(2): 199-215.

Faullant R, K. Matzler, and T.A. Mooradian. (2011). "Personality, Basic Emotions, and Satisfaction: Primary Emotions in the Mountaineering Experience.” Tourism Management. 32 (6): 1423-30.

Fischer GN. 1992. Psychologie Sociale de l'Environnement. Privat: Toulouse, France.

Grinderberg A.Y., Shoval N. \& McKercher B. (2014) Typologies of tourists' time-space consumption;: a new approach using GPS data and GIS tools, Tourism Geographies, 16: $1-19$.

Hansen A.H. and Mossberg L. (2016) Tour guide's performance and tourists' immersion: facilitating consumer immersion by performing a guide plus role, Scandinavian Journal of hospitality and Tourism, July: 1-20.

Heidegger, M. (1962). Being and time. New York: Harper. (Original work published 1927)

Holt D.B. (1995), “How Consumers Consume: A Typology of Consumption Practices”, Journal of Consumer Research, 22, June, 1-16.

Ingold T, Kurtilla T, (2000) "Perceiving the environment in Finnish Lapland" Body and 
Society $6183-196$.

Ingram C., Caruana R. and McCabe S. (2017) PARTicipative inquiry for tourist experience, Annals of Tourism Research, 65: 13-24.

Jafari J. (1987) Tourism models: the socio-cultural aspects, Tourism Management, Vol8(2): 151-159.

Jansson A. (2007) A sense of tourism: new media and the dialectic of encapsulation/decapsulation, Tourist Studies. 7(1) : 5-24.

Kaaristo M. and Rhoden S. (2016) Everyday life and water tourism mobilities: mundane aspects of canal travel, Tourism Geographies, pages 1-18.

Komppula, R., I. Riikka and D. Airey. (2016). "Social Holidays as a Tourist Experience in Finland." Tourism Management. $52: 521-532$.

Ladwein R. (2002), “Voyage à Tikidad : de l'accès à l'expérience de consommation”, Décisions Marketing, 28, octobre-décembre, 53-63.

Laing J. and Frost W. (2017) Journeys of well-being : women's travel narratives of transformation and self-discovery in Italy, Tourism Management : 102-119.

Larsen, J (2008) De-exoticizing tourist travel: everyday life and sociality on the move, Leisure Studies, 27(1): 21-34.

Larsen J. (2007) Aspects for a psychology of the tourist experience, Scandinavian Journal of Hospitality and tourism, 7 (1): 7-18.

Larsen J. and Kirkegaard R. (2013) The pleasures of being together in a holiday home, Scandinavian Journal of Hospitality and tourism, 13(3): 153-174.

Lee Y., Dattilo J. \&Howard D. (1994) The complex and dynamic nature of leisure experiences, Journal of Leisure Research, 26(3): 195-211. 
Miles M.B., Huberman A.M. \& Saldana J. (2013), Qualitative Data Analysis, Sage publishing ( $3^{\text {rd }}$ edition).

Maslow A.H. (1943) A theory of human motivation, Psychological Review, Vol 50(4), Jul 1943, 370-396.

Matteucci X. and Gnoth J. (2017) Elaborating on grounded theory in tourism research, Annals of Tourism Research, 65: 49-59.

McCabe S. (2002) The tourist experience and everyday life, in: Dann G.M.C. (ed) The tourist as a metaphor of the social world, Cabi Publishing: Oxon, pages 61-75.

McKercher B. and Lui S-L (2014) Becoming a tourist, International Journal of Tourism Research, 16: 399-406.

McKercher B., Shoval N., Ng E. (2012) First and repeat visitor behaviour: GPS tracking and GIS analysis in Hong-Kong, Tourism Geographies, 14(1): 147-161.

Mels T. (2004) Reanimating places: a geography of rhythms, Aldershot: Ashgate.

Moutsakas C. (1994) Phenomenological research methods, Thousand Oaks: Sage.

Nawijn J. (2010) The holiday happiness curve: a preliminary investigation into mood during a holiday abroad, International Journal of Tourism research, 12: 281-290.

O’Dell, T. and P. Billing (2005). "Experiencescapes: Tourism, Culture and Economy." Copenhagen Business School Press.

Otto, J.E. and J.B.R. Ritchie. (1996). "The Service Experience in Tourism.” Tourism Management. 17 (3): 165-74.

Pearce P.L. \& Caltabiano M.L. (1983) Inferring Travel Motivation from Travelers' Experiences, Journal of Travel Research, Vol 22(2): 16 - 20

Pearce P.L. (1981) “Environment chock": a study of tourists' reactions to two tropical 
islands", Journal of Applied Social Psychology, 11(3): 268-280.

Pomfret G. (2006). "Mountaineering Adventure Tourists: A Conceptual Framework for Research.” Tourism Management. 27(1): 113-23.

Pomfret G. (2011). "Package Mountaineer Tourists Holidaying in the French Alps: An Evaluation of Key Influences Encouraging their Participation.” Tourism Management. 32 (3): $501-10$.

Pritchard, A. and N. Morgan. (2006). "Hotel Babylon? Exploring Hotels as Liminal Sites of Transgression and Transition”. Tourism Management. 27(3): 283-302.

Reckwitz A. (2002) Toward a theory of social practices A development in Culturalist theorizing, European Journal of Social Theory, 5(2) : 253-263.

Reiners G.M. (2012) Understanding the differences between Husserl's (descriptive) and Heidegger's (interpretative) phenomenological research, Journal of Nursing and Care, Vol 1(5): 1-5.

Rojek, C. and J. Urry (1997) Touring Cultures: Transformations of Travel and Theory. London: Routledge.

Ryan C. (1995) Learning about tourists from conversations: the over -55s in Majorca, Tourism Management, 16(3): 207-215.

Seamon, D. (1979). A geography of the lifeworid. New York: St. Martin's.

Schouten, J and McAlexander, H (1995) Subcultures of Consumption: An Ethnography of the New Bikers. Journal of Consumer Research, Vol. 22, 43-61

Simpson P. (2012) Apprehending everyday rhythms: rhythm analysis, time-lapse photography, and the space-times of street performance, Cultural Geographies, 19(4): 423-445.

Sørensen F. and Jensen J.F. (2015) Value creation and knowledge development in tourism 
experience encounters, Tourism Management, 46: 336-346.

Turner. V. \& Turner E. (1978) Image and Pilgrimage in Christian Culture. Basil Blackwell: Oxford.

Tussyadyah L.P. (2014) Toward a Theoretical Foundation for Experience Design in Tourism, Journal of Travel Research, Vol. 53(5): 543-564.

Tussyadyah L.P. \& Zach F.J. (2012) The role of geobased technology in place experience, Annals of Tourism Research, 39(2): 780-800.

Urry J. (1990) The "consumption” of tourism, Sociology, 24(1): 23-35.

Van Gennep A.(1909) Les rites de Passage, Les CLassiques des Sicences Sociales, 1981, numeric book: http://classiques.uqac.ca/

Wang (1999) Rethinking authenticity in tourist experience, Annals of Tourism Research, 26(2): 349-370.

Windsong E.A. (2010) There is no place like home: Complexities in exploring home and place attachment, The Social Science Journal, Volume 47, Issue 1, January 2010, Pages $205-214$ 